\title{
RESPON PERTUMBUHAN BENIH KERAPU BEBEK (Cromileptes altivelis) PADA PERLAKUAN PERBEDAAN SALINITAS MEDIA DAN PEMBERIAN BIOMAS Artemia sp. DEWASA
}

\author{
Growth Response of Juvenile Kerapu Bebek (Cromileptes altivelis) \\ at Treatments with Different Salinity and Adult Artemia Biomass \\ Luky Mudiarti dan Muhammad Zainuddin \\ Program Studi Budidaya Perairan, F.Saintek, Universitas Islam Nahdlatul Ulama Jepara \\ Jl. Taman Siswa (Pekeng) Tahunan, Jepara - Jawa Tengah 59427, Indonesia \\ Email: mlukymudiarti@yahoo.co.id
}

Diserahkan tanggal 6 Juni 2016, Diterima tanggal 18 Juli 2016

\begin{abstract}
ABSTRAK
Pertumbuhan Ikan Kerapu budidaya dipengaruhi oleh beberapa faktor, diantaranya adalah salinitas dan pakan. Tujuan penelitian ini adalah mengkaji pertumbuhan benih Kerapu Bebek pada perlakuan perbedaan salinitas media dan pemberian biomas Artemia sp. dewasa. Materi yang digunakan adalah benih Kerapu Bebek (C. altivelis). Penelitian dilakukan dengan metode eksperimental laboratoris dengan rancangan acak lengkap berpola faktorial $(3 \times 3)$. Sebagai variabel dependen penelitian pada faktor satu adalah persentase pemberian biomas Artemia sp. (150\%, 200\%, 250\%), sedangkan faktor dua adalah salinitas media (27 ppt, $31 \mathrm{ppt}$ dan 35 ppt). Sehingga terdapat 9 varian percobaan dangan masing-masing 3 ulangan. Sebagai variabel independen adalah panjang $(\mathrm{cm})$ dan berat kerapu (gram). Lama pemeliharaan kerapu 60 hari. Analisis data untuk mengetahui perbedaan antar perlakuan menggunakan ujiF dengan bantuan program SPSS. Hasil analisis two way anova menunjukkan bahwa tidak terdapat interaksi antara perlakuan pemberian biomassa dan salinitas media terhadap panjang kerapu. Perlakuan biomassa memberikan pengaruh signifikan terhadap panjang relatif yaitu $74^{\mathrm{a}}, 98^{\mathrm{b}}$ dan $103^{\mathrm{b}}$. Analisis regresi menunjukkan bahwa terdapat hubungan polinomial yaitu semakin tinggi pemberian Artemia sp. maka panjang relatif semakin meningkat. Analisis two way anova perlakuan salinitas memberikan pengaruh signifikan terhadap panjang relatif yaitu $85^{\mathrm{a}}, 98^{\mathrm{b}}$ dan $92^{\mathrm{b}} \%$. Perlakuan pemberian Artemia sp. memberikan pengaruh signifikan terhadap berat relatif yaitu $505^{\mathrm{a}}, 834^{\mathrm{b}}$ dan $861^{\mathrm{b}} \%$. Sedangkan perlakuan salinitas media memberikan pengaruh signifikan terhadap panjang relatif yaitu $719^{\mathrm{a}}, 764^{\mathrm{b}}$ dan $718^{\mathrm{a}} \%$. Analisis one way anova interaksi perlakuan menunjukkan bahwa perlakuan Artemia sp. $150 \%$ pada salinitas $31 \mathrm{ppt}$ memiliki nilai berat relatif terendah yaitu $497 \%$, sedangkan perlakuan artemia $200 \%$ pada salinitas $31 \mathrm{ppt}$ memiliki nilai berat relatif tertinggi yaitu $927 \mathrm{~d} \%$.
\end{abstract}

Kata kunci: Salinitas, Artemia sp., Panjang, Berat, Kerapu

\begin{abstract}
Aquaculture grouper is influenced by several factors, such as salinity and feed. The purpose of this study is to assess the growth of humpback grouper seed in the treatment of salinity and biomass Artemia sp.. The material used is the humpback grouper $(C$. altivelis). The study was conducted with experimental laboratory method with a completely random design patterned factorial ( $3 \times 3)$. As the dependent variable of research on one factor is the percentage of biomass Artemia sp. (150\%, 200\%, 250\%), while the two factors is a salinity (27 ppt, 31 ppt and 35 ppt). So that there are nine variants with 3 replicates. As the independent variable is the length $(\mathrm{cm})$ and weight of grouper (grams). The grouper culture in 60 days. Data analysis to determine differences treatments using F-test with SPSS. Two way ANOVA analysis results that there is no interaction between treatment of biomass and salinity to the length of grouper. The treatment of biomass has significant impact on the relative lengths namely $74^{a}, 98^{b}$ and $103^{b}$. Regression analysis showed that there is a polynomial relationship the higher biomass of Artemia sp. the relative length increases. Two way ANOVA analysis of salinity treatment a significant effect on the relative lengths namely $85^{a}$, $98^{b}$ and $92^{b} \%$. Treatment biomass Artemia sp. a significant effect on the relative weight that is $505^{a}, 834^{b}$ and $861^{b} \%$. While the salinity treatments significant impact on the relative lengths of which $719^{a}, 764^{b}$ and $718^{a} \%$. Analysis of the interaction one way ANOVA showed that the treatment Artemia $150 \%$ at salinity 31 ppt has the lowest value relative weight that is $497^{a} \%$, while the brine treatment $200 \%$ at a salinity of 31 ppt has the highest relative weight value $927^{\mathrm{d}} \%$.
\end{abstract}

Keywords: salinity, Artemia sp., length, weight, grouper

(ㄷ) Copyright by Saintek Perikanan (Indonesian Journal of Fisheries Science and Technology), ISSN : 1858-4748 


\section{PENDAHULUAN}

Kerapu Bebek merupakan salah satu jenis ikan air laut yang sangat digemari konsumen dan mempunyai harga yang cukup tinggi hingga mencapai $\mathrm{Rp} 400.000,-/ \mathrm{Kg}$ di pasar lokal maupun internasional (Suriawan et al., 2003). Keberhasilan budidaya kerapu baik di KJA maupun di tambak sangat dipengaruhi oleh keberadaan infeksi penyakit oleh bakteri patogen pada benih yang dipelihara. Salah satu upaya untuk mengatasi masalah tersebut adalah dengan melakukan usaha pendederan terlebih dahulu sebelum benih digunakan untuk usaha pembesaran. Kendala yang sering dihadapi saat pendederan benih Kerapu Bebek adalah rendahnya pertumbuhan $(1,5 \%$ /hari) akibat ketidakcocokan pakan diberikan dan salinitas media hidup. Kerapu memperoleh energi dari pakan yang dikonsumsi dan kehilangan energi sebagai akibat adanya metabolisme, terutama untuk keperluan pemeliharaan osmoregulasi. Efisiensi pemanfaatan energi untuk pertumbuhan sangat bergantung kepada daya dukung kondisi lingkungannya. Pemanfaatan energi pakan bagi pertumbuhan kerapu akan efisien bila ikan tersebut hidup di media yang tidak jauh dari kondisi isoosmotik. Oleh karena itu, penelitian ini memiliki tujuan untuk mengkaji pengaruh perbedaan salinitas media dan pemberian biomas Artemia sp. dewasa terhadap pertumbuhan benih kerapu bebek.

\section{METODE PENELITIAN}

\section{Hewan uji}

Hewan uji yang digunakan dalam penelitian ini adalah benih kerapu bebek dari satu induk yang diperoleh dari Balai Pengembangan Budidaya Air Payau Jepara, stadia D60 yang berukuran panjang 3,1-3,5 $\mathrm{cm}$ dan berat $0,451 \pm 0,02 \mathrm{~g}$ (Antoro et al., 2004).

\section{Pakan uji}

Pakan yang diberikan untuk benih kerapu adalah Artemia sp. dewasa (14 hari dari saat menetas, dengan panjang minimal $0,6 \mathrm{~cm}$ ) yang telah diperkaya dengan minyak ikan. Pemberian minyak ikan dengan dosis $300 \mathrm{mg} / \mathrm{l}$ selama 12 jam (Leger et al., 1997).

\section{Wadah pemeliharaan}

Wadah pemeliharaan adalah ember plastik berkapasitas 10 1. Wadah dengan volume 101 sebanyak 27 buah diisi dengan air sebanyak 81 tiap ember dengan kepadatan 1 ekor/l, sehingga setiap wadah dapat menampung ikan sebanyak 8 ekor (Antoro et al., 2004).

\section{Tahap pelaksanaan}

Penelitian dilakukan dengan metode eksperimental laboratoris dengan rancangan acak lengkap berpola faktorial (3x3). Sebagai variabel dependen penelitian pada faktor satu adalah prosentase pemberian Artemia sp. (150\%, 200\%, $250 \%$ ), sedangkan faktor dua adalah salinitas media (27 ppt, 31 ppt dan 35 ppt). Sehingga terdapat 9 varian percobaan dangan masing - masing 3 ulangan. Sembilan varian perlakuan tersebut adalah (1). perlakuan persentase pemberian Artemia sp $150 \%$ pada salinitas $27 \mathrm{ppt}$; (2). $150 \%$ pada $31 \mathrm{ppt}$; (3). $150 \%$ pada 35 ppt; (4). $200 \%$ pada 27 ppt; (5). $200 \%$ pada 31 ppt; (6). $200 \%$ pada $35 \mathrm{ppt}$; (7). $250 \%$ pada $27 \mathrm{ppt}$; (8). $250 \%$ pada 31 ppt; dan (9). $250 \%$ pada 35 ppt. Sedangkan sebagai variabel independen adalah panjang $(\mathrm{cm})$ dan berat kerapu (gram). Pemberian pakan dilakukan dua kali sehari secara satiasi pada pukul 06.00 dan pukul 18.00. Jumlah pakan yang diberikan dilakukan penyesuaian tiap 10 hari berdasarkan umur ikan. Pengamatan pertumbuhan dilakukan selama 60 hari pemeliharaan. Selama penelitian dilakukan penggantian air setiap hari sebanyak 50\% dari volume air dengan air media pengganti yang telah dipersiapkan sebelumnya untuk setiap perlakuan.

\section{Analisis Data}

Data dilakukan analisis ragam untuk mengetahui perbedaan / ada tidaknya pengaruh antar perlakuan yang diteliti, dilakukan ANOVA dua jalur dengan SPSS 16 terhadap variabel-variabel yang diamati (Ghozali, 2005). Analisis regresi model polynomial orthogonal diaplikasikan guna melihat respon peubah (variabel dependen) terhadap variabel independent.

\section{HASIL DAN PEMBAHASAN}

Penelitian dilaksanakan selama 60 hari pemeliharaan benih kerapu dengan perlakuan pemberian Artemia sp. dan salinitas media. Pengamatan dilakukan terhadap data panjang dan berat ikan kerapu. Hasil uji two way anova Tabel 1 menunjukkan bahwa perlakuan perbedaan pemberian biomasa Artemia sp. dan salinitas media memberikan pengaruh signifikan $(\mathrm{p}<0,05)$ terhadap pertumbuhan panjang relatif benih ikan kerapu dengan nilai $\mathrm{F}$ hitung 76,88 dan 14,52. Akan tetapi antara perlakuan perbedaan pemberian biomasa Artemia sp. dengan perlakuan perbedaan salinitas media tidak terjadi interaksi terhadap pertumbuhan panjang relatif benih Ikan Kerapu dengan nilai F hitung 0,197 dan Sig. 0,936.

Tabel 1. Analisis two way anova perlakuan terhadap panjang relatif (\%)

\begin{tabular}{cccccc}
\hline Variabel & $\mathrm{n}$ & $\mathrm{df}$ & $\mathrm{x}^{2}$ & $\mathrm{~F}$ & Sig. \\
\hline Artemia & 3 & 2 & 2198,5 & 76,88 & 0,000 \\
Salinitas & 3 & 2 & 415,25 & 14,52 & 0,000 \\
Artemia*Salinitas & 6 & 4 & 5,64 & 0,197 & 0,936 \\
\hline
\end{tabular}

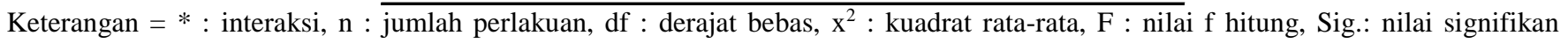
dengan $\alpha: 0,05$

Berdasarkan histogram Gambar 1 menunjukkan bahwa perlakuan pemberian biomassa Artemia sp. $150 \%$ memberikan nilai pertumbuhan panjang relatif terendah dengan nilai $74 \%$. Sedangkan perlakuan biomassa Artemia sp. $250 \%$ memberikan panjang relatif tertinggi sebesar 103\%. Berdasarkan hasil analisis one way anova perlakuan biomassa Artemia sp. memberikan pengaruh signifikan $(\mathrm{p}<0,05)$ terhadap panjang relatif benih Ikan Kerapu. 


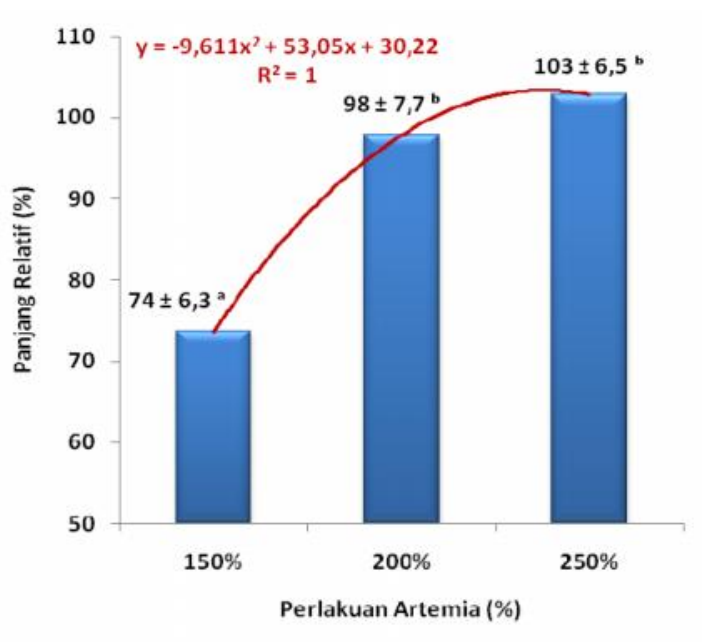

Gambar 1. Pengaruh pemberian biomassa Artemia terhadap panjang relatif $(\%)$

Hasil uji lanjut Tukey Gambar 1 menunjukkan bahwa respon panjang relatif pada perlakuan biomassa Artemia sp. $200 \%$ dan $250 \%$ saling tidak berbeda nyata $(\mathrm{p}<0,05)$. Tetapi kedua perlakuan tersebut berbeda nyata $(\mathrm{p}<0,05)$ terhadap biomassa $150 \%$.

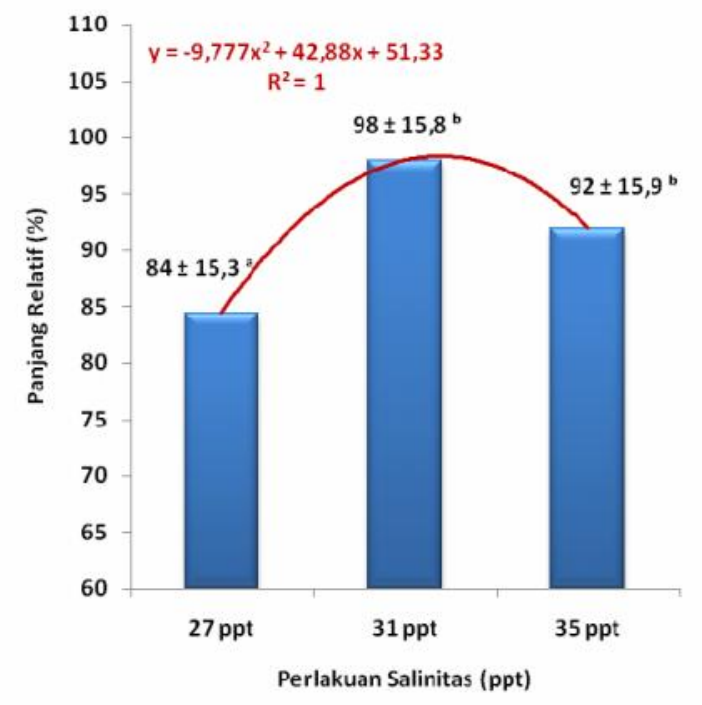

Gambar 2. Pengaruh perbedaan salinitas media terhadap panjang relatif $(\%)$
Berdasarkan analisis regresi Gambar 1 menunjukkan bahwa terdapat hubungan polinomial yaitu semakin tinggi pemberian Artemia sp. maka panjang relatif semakin meningkat dengan persamaan $\mathrm{Y}=-9,611 \mathrm{x}^{2}+53,05 \mathrm{x}+30,22$. Hal ini terkait dengan kandungan protein pakan yang diperoleh ikan akan dipergunakan untuk diubah menjadi energi yang diperlukan bagi metabolisme di dalam tubuh dan energi yang masih tersisa digunakan untuk mendukung pertumbuhan (Halver, 1999). Berdasarkan tren polinomial tersebut menunjukkan terjadi peningkatan panjang relatif yang signifikan dari $150 \%$ ke $200 \%$. Nilai optimal biomassa Artemia sp. terhadap panjang diduga terdapat di antara konsentrasi 200 dan $250 \%$, kemudian mulai terjadi penurunan pada konsentrasi $250 \%$. Tren polinomial tersebut menunjukkan jika konsentrasi biomassa Artemia sp. ditingkatkan lebih dari $250 \%$ maka akan memberikan respon panjang relatif semakin kecil.

Berdasarkan histogram Gambar 2 menunjukkan bahwa perlakuan perbedaan salinitas 27 ppt media memberikan nilai pertumbuhan panjang relatif terendah dengan nilai $84 \%$. Sedangkan perlakuan 31 ppt memberikan panjang relatif tertinggi sebesar 98\%. Berdasarkan hasil analisis one way anova perlakuan salinitas media memberikan pengaruh signifikan $(\mathrm{p}<0,05)$ terhadap panjang relatif benih Ikan Kerapu. Hasil uji lanjut Tukey menunjukkan bahwa respon panjang relatif pada perlakuan salinitas 31 dan 35 ppt saling tidak berbeda nyata $(\mathrm{p}<0,05)$. Tetapi kedua perlakuan tersebut berbeda nyata $(\mathrm{p}<0,05)$ terhadap salinitas $27 \mathrm{ppt}$.

Berdasarkan analisis regresi Gambar 2 menunjukkan bahwa terdapat hubungan polinomial dengan persamaan $\mathrm{y}=$ $9,611 x^{2}+53,05 x+30,22$. Berdasarkan tren polinomial tersebut menunjukkan terjadi peningkatan panjang relatif yang signifikan dari salinitas 27 ppt ke 31 ppt. Nilai optimal salinitas terhadap panjang adalah perlakuan 31 ppt, kemudian mulai terjadi penurunan pada salinitas $35 \mathrm{ppt}$. Hasil yang terbaik pada perlakuan 31 ppt merupakan salinitas media isoosmotik bagi Kerapu Bebek, dimana energi yang paling besar digunakan untuk menunjang pertumbuhannya. Perlakuan 31 ppt terhadap ikan mengalami proses fisiologis yang lebih baik dimana cairan tubuh ikan mempunyai sifat yang sama (seimbang) dengan cairan medianya, sehingga energi yang diperoleh dari pakan akan digunakan untuk pertumbuhan. Pesatnya pertumbuhan ikan pada media dengan salinitas yang isoosmotik mengakibatkan kerja osmotik yang dialami ikan relatif kecil sehingga lebih banyak porsi energi yang dipakai untuk pertumbuhan.

Tabel 2. Analisis two way anova perlakuan terhadap berat relatif (\%)

\begin{tabular}{ccccccc}
\hline Variabel & $\mathrm{n}$ & $\mathrm{df}$ & $\mathrm{x}^{2}$ & $\mathrm{~F}$ & Sig. \\
\hline Artemia & 3 & 2 & 353486 & 593,17 & 0,000 \\
Salinitas & 3 & 2 & 6274,9 & 10,53 & 0,001 \\
Artemia*Salinitas & 6 & 4 & 6831,7 & 11,46 & 0,000 \\
\hline
\end{tabular}

Keterangan $=*$ : interaksi, $\mathrm{n}:$ jumlah perlakuan, df $:$ derajat bebas, $\mathrm{x}^{2}:$ kuadrat rata-rata, $\mathrm{F}:$ nilai $\mathrm{f}$ hitung, Sig. : nilai signifikan dengan $\alpha: 0,05$.

Hasil uji two way anova Tabel 2 menunjukkan bahwa perlakuan perbedaan pemberian biomasa Artemia sp. dan salinitas media memberikan pengaruh signifikan $(\mathrm{p}<0,05)$ terhadap pertumbuhan berat relatif benih ikan kerapu dengan nilai $\mathrm{F}$ hitung 598,17 dan 10,53. Berdasarkan histogram Gambar 3 menunjukkan bahwa perlakuan pemberian biomassa Artemia sp. $150 \%$ memberikan nilai pertumbuhan berat relatif terendah dengan nilai 505\%. Sedangkan perlakuan biomassa 
Respon Pertumbuhan Benih Kerapu Bebek pada Perlakuan Perbedaan Salinitas Media dan Pemberian Biomas Artemia Sp. Dewasa

Artemia sp. $250 \%$ memberikan panjang relatif tertinggi sebesar $861 \%$.

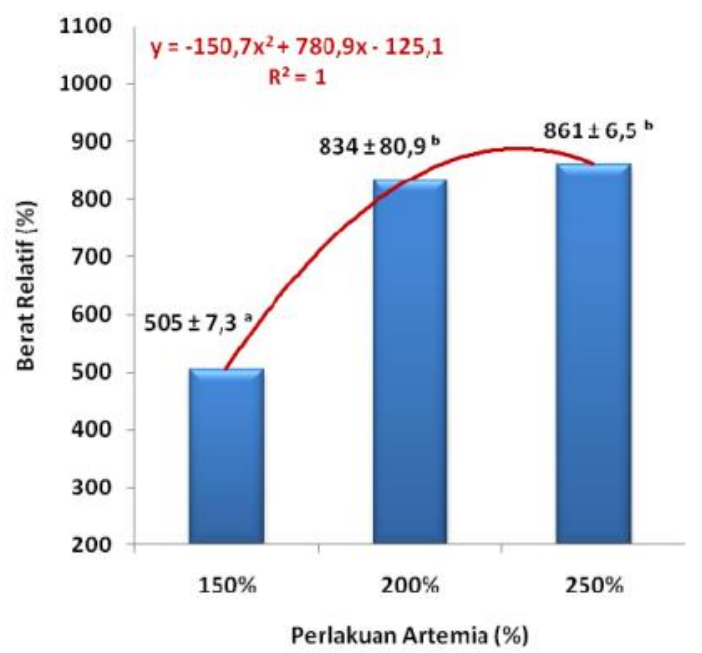

Gambar 3. Pengaruh pemberian biomassa Artemia sp terhadap berat relatif $(\%)$

Berdasarkan analisis regresi Gambar 3 menunjukkan bahwa terdapat hubungan polinomial yaitu semakin tinggi pemberian Artemia sp. maka berat relatif semakin meningkat dengan persamaan $\mathrm{y}=-150,7 \mathrm{x}^{2}+780,9 \mathrm{x}-125,1$. Berdasarkan tren polinomial tersebut menunjukkan terjadi peningkatan berat relatif yang signifikan dari $150 \%$ ke $200 \%$. Nilai optimal biomassa Artemia sp. terhadap berat diduga terdapat di antara konsentrasi 200 dan $250 \%$, kemudian mulai terjadi penurunan pada konsentrasi $250 \%$.

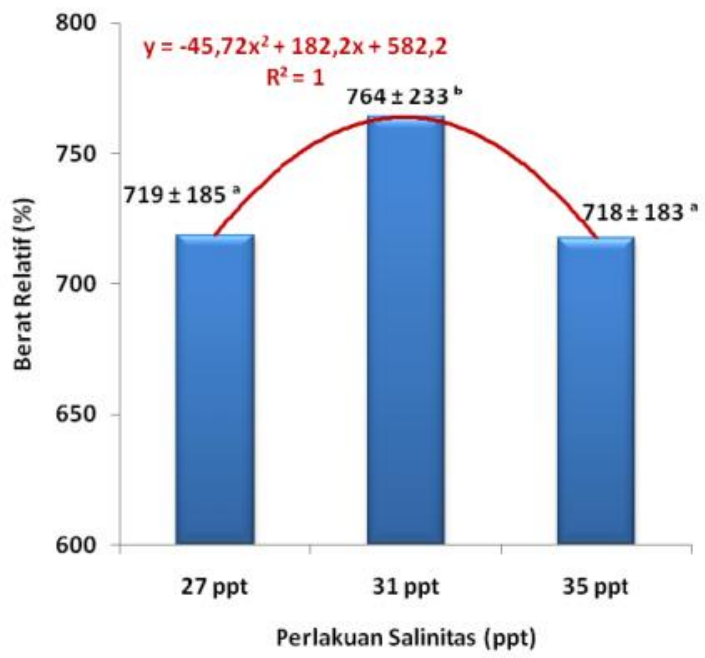

Gambar 4. Pengaruh perbedaan salinitas media terhadap berat relatif $(\%)$
Tren polinomial tersebut menunjukkan jika konsentrasi biomassa Artemia sp. ditingkatkan lebih dari $250 \%$ maka akan memberikan respon berat relatif semakin kecil. Perbedaan pertumbuhan berat diantara perlakuan yang diujikan disebabkan perbedaan tingkat energi pakan. Ikan dikenal memenuhi sebagian kebutuhan energinya dari protein pakan, sehingga pakan mempunyai pengaruh besar atas efisiensi penggunaan energi dan protein. Hasil penelitian Sunyoto (2005), kandungan EPA dari Artemia sp. yang diperkaya dengan minyak hati cod adalah $10,54 \%$ dari total lemak, kandungan DHA nya sebesar $9,94 \%$ dari total lemak. Sedang hasil penelitian Yushinta (2003) Artemia sp. yang telah diperkaya dengan omega-3 menghasilkan kandungan DHA 9,81\% dan EPA sebesar 10,84\%. Merujuk beberapa hasil penelitian tersebut diatas bahwa kerapu setelah diberikan pakan Artemia sp. yang diperkaya dengan asam lemak omega-3 akan mengalami kenaikan kandungan EPA dan DHA nya. Purba (2006) bahwa kandungan EPA dan DHA pada kerapu adalah $2,49 \%$ dan $0,376 \%$, kemudian setelah diberi pakan dengan Artemia sp. yang telah diperkaya kandungan omega-3 nya, maka kandungan EPA nya naik menjadi $7,809 \%$ dan kandungan DHA nya menjadi 4,964\%.

Berdasarkan histogram Gambar 4 menunjukkan bahwa perlakuan perbedaan salinitas $35 \mathrm{ppt}$ media memberikan nilai pertumbuhan berat relatif terendah dengan nilai $718 \%$. Sedangkan perlakuan $31 \mathrm{ppt}$ memberikan berat relatif tertinggi sebesar 764\%. Berdasarkan hasil analisis one way anova perlakuan salinitas media memberikan pengaruh signifikan ( $\mathrm{p}$ $<0,05)$ terhadap berat relatif benih Ikan Kerapu. Hasil uji lanjut Tukey menunjukkan bahwa respon berat relatif pada perlakuan salinitas 27 dan 35 ppt saling tidak berbeda nyata ( $\mathrm{p}$ $<0,05$ ). Tetapi kedua perlakuan tersebut berbeda nyata ( $\mathrm{p}<$ $0,05)$ terhadap salinitas $31 \mathrm{ppt}$. Berdasarkan analisis regresi menunjukkan bahwa terdapat hubungan polinomial dengan persamaan $\mathrm{y}=-45,72 \mathrm{x}^{2}+182,2 \mathrm{x}+582,2$. Berdasarkan tren polinomial tersebut menunjukkan terjadi peningkatan panjang relatif yang signifikan dari salinitas 27 ppt ke 31 ppt. Nilai optimal salinitas terhadap panjang adalah perlakuan $31 \mathrm{ppt}$, kemudian mulai terjadi penurunan pada salinitas $35 \mathrm{ppt}$.

Hasil uji two way anova Tabel 2 menunjukkan bahwa antara perlakuan perbedaan pemberian biomasa Artemia sp. dengan perlakuan perbedaan salinitas media terjadi interaksi terhadap pertumbuhan panjang relatif benih ikan kerapu dengan nilai $\mathrm{F}$ hitung 11,46. Berdasarkan hasil analisis one way anova interaksi perlakuan Gambar 5 menunjukkan terdapat pengaruh signifikan $(\mathrm{p}<0,05)$ terhadap berat relatif benih ikan kerapu. Hasil uji lanjut Tukey menunjukkan bahwa perlakuan biomasa Artemia sp. $150 \%$ pada salinitas 31 ppt memberikan respon berat relatif terendah sebesar $497 \%$ yang tidak berbeda nyata dengan perlakuan biomasa $150 \%$ pada salinitas $27 \mathrm{ppt}$ dan 35 ppt. Sedangkan perlakuan biomasa Artemia sp. $200 \%$ pada salinitas $31 \mathrm{ppt}$ memberikan respon berat relatif tertinggi sebesar $927 \%$ yang secara signifikan $(\mathrm{p}<0,05)$ berbeda nyata dengan interaksi perlakuan yang lainnya. 


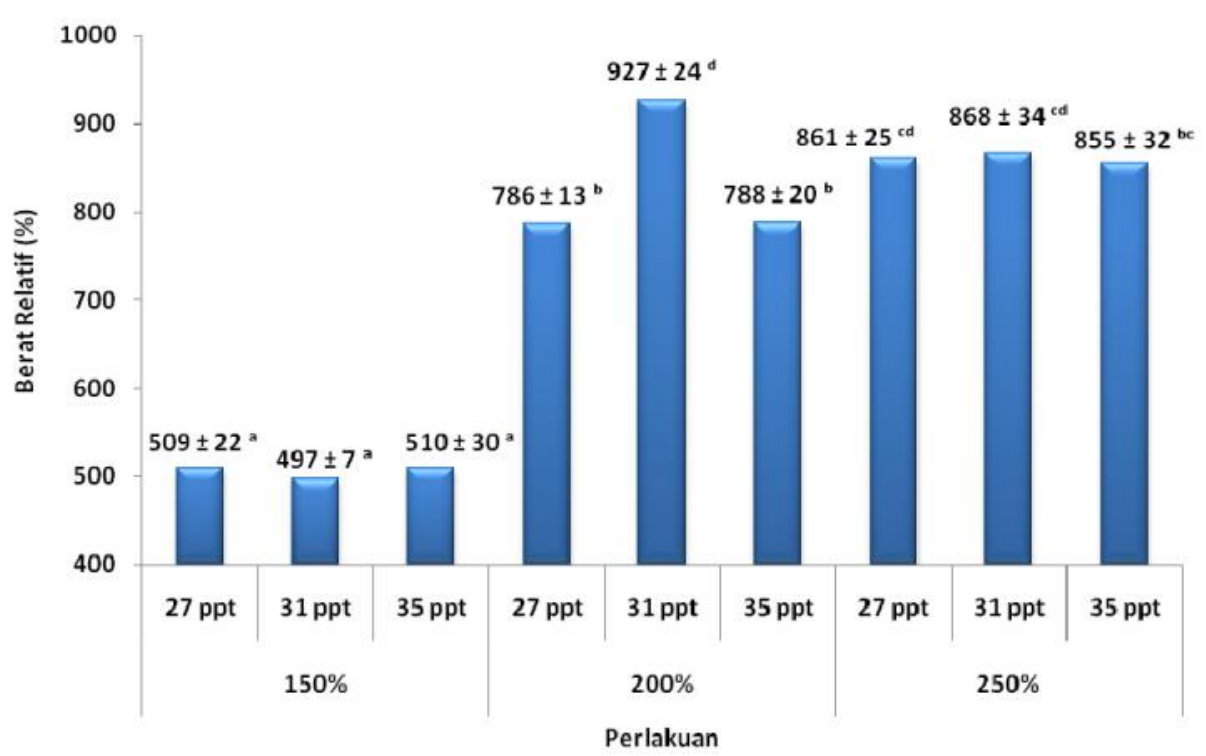

Gambar 5. Pengaruh interaksi perlakuan terhadap berat relatif (\%)

\section{KESIMPULAN}

Perlakuan perbedaan pemberian biomassa Artemia sp. dan salinitas media memberikan pengaruh signifikan $(p<0,05)$ terhadap pertumbuhan panjang dan berat relatif ikan kerapu. Hasil interaksi perlakuan biomassa dan salinitas menunjukkan bahwa perlakuan biomassa artemia $200 \%$ pada salinitas $31 \mathrm{ppt}$ memiliki nilai pertumbuhan berat relatif tertinggi.

\section{UCAPAN TERIMA KASIH}

Kami penulis menyampaikan ucapan terima kasih kepada Prof. Dr. Ir. Sutrisno Anggoro, MS dan Dr. Ir. Agung Sudaryono, MSc. dari FPIK Universitas Diponegoro Semarang, yang telah membantu dalam jalannya penelitian. Sehingga, penelitian dapat berjalan dengan lancar dan publikasi dapat diterbitkan.

\section{DAFTAR PUSTAKA}

Antoro, S., H. A. Sarwono, dan Sudjiharno. 2004. Biologi Kerapu. dalam: Pembenihan Ikan Kerapu, Seri Budidaya Laut (3). Balai Budidaya Laut Lampung. Hlm 4-11.

Ghozali, I. 2005. Aplikasi Analisis Multivariat dengan Program SPSS. Badan Penerbit Universitas Diponegoro, Semarang. $159 \mathrm{hlm}$.
Halver, J.E. 1999. Fish Nutrition. Second Edition. Academic Press, Inc. 798 pp.

Leger, P., E. Naeessens-Foucquaert., and P. Sorgeloos. 1997. Techniques to Manipulate The Fatty Acid Profile in Artemia naupli and The Effects on Its Nutritional Effectiveness for The Marine Crustaceans Mysidopsis bahia. Aquaculture. 3: 411-424.

Purba, T. 2006. Peningkatan Gizi Rotifer Pakan Larva Ikan Kerapu Macan. Warta Penelitian dan Pengembangan Pertanian, 17 (1): 4-6.

Sunyoto, P. Waspada., dan Mustahal. 2005. Peningkatan Gizi Nauplius Artemia Salina untuk Larva Ikan Laut Dengan Pengkayaan Menggunakan Emulsi Lemak. Jurnal Penelitian Budidaya Pantai, 8(3):34-44.

Suriawan,A., A. Haryono., dan S. Wahyuningsih. 2003. Teknik Pembenihan Ikan Kerapu. dalam : Pelatihan Pembenihan Ikan Multi Spesies untuk Pengelola BBIP di BBAP Situbondo, 25 Agustus-20 September dan 25 September-Oktober 2003. Balai Budidaya Air Payau Situbondo. Hlm 1-10.

Yushinta, F., Yusri, K. Soetenis., S. Hasnah. 2003. Karotenoid dan Asam Lemak Omega-3 Larva Kepiting (Scylla serrata) sebagai Nutrisi Tambahan untuk Meningkatkan Sintasan Larva Kepiting Bakau. Fakultas Ilmu Kelautan dan Perikanan, Universitas Hassanuddin. Makasar. $8 \mathrm{hlm}$. 